\title{
TRANSLATION STRATEGIES IN POLITICAL SPEECHES: a case study of Ukrainian translation of president Joseph R. Biden's inaugural address
}

Keywords: translation strategy; inaugural address; political discourse; source text; communicative intent; target language.

ABSTRACT: The paper deals with a comprehensive study of translation strategies in English-Ukrainian translation of President Joseph R. Biden's inaugural address. Political discourse is characterized by its unique features triggering a considerable interest in applied linguistics and translation studies. In brief, political speeches are often delivered by politicians to communicate their messages to the public. They mainly operate as a tool of persuasion, imposing political ideas, beliefs, and practices crucial in constituting a political community.

Translating political speeches can posit serious problems due to their unique features as a special text genre. Appropriate translation methods are needed to ensure a higher quality political speech translation and its adequacy. It has been decided that the best methods for the proposed study were discourse and comparative analyses combined with generalization. The translation techniques employed in the translation of Joseph R. Biden's inaugural address into Ukrainian include lexical, grammatical, and complex transformations.

A comparative analysis of the linguistic means used by both American president and the translator has demonstrated that the source text submitted for translation undergoes interlingual changes to create the text with the same communicative intent in the target language. Syntactic translation transformations are the most dominant ones, followed by lexical and grammatical. Such changes in the translation of the American President's inaugural address are necessary for better conforming to existing cultural norms and soothing out social, religious,

1 Faculty of Foreign Philology, Uzhhorod National University, Universytetsyka str., 14, 88-000 Uzhhorod, Ukraine, e-mail: halyna.onyshchak@uzhnu.edu.ua, ORCID ID: https://orcid.org/0000-0002-5133-4313. 
and political differences in English and Ukrainian cultures. Thus, translation is not simply an act of faithful reproduction but, rather, deliberate and conscious creation of secret linguistic and pragmatic codes.

\section{INTRODUCTION}

The fundamental features of today's world are globalization and technological advancements. The former is generally associated with "the shrinking of our world and the possibility of instant communication across the globe" (Bielsa, Bassnett, 2009, p. 18). What is particular about the current phase of globalization is that politics pervades over lives since it has a powerful impact on our social, religious, and historical aspects. Language is not an exception. Yielding a uniquely human perspective (in the form of a conceptual structure) on the world (Asoulin, 2016, p. 17), it operates as a "primary mechanism for "storing" and communicating cultural cognition, acting both as a memory bank and a fluid vehicle for the (re-)transmission of cultural cognition" (Sharifian, 2017, p. 5). Viewed in this way, there is a remarkably close link between the life of society and the language spoken by it. Political communication is concerned with all public and private talk about political issues, which are plausible candidates for lexicalization. The primary tool used by most politicians to reach their goals is a political speech. The latter aims at convincing the audience to accept the proposed idea, action, or beliefs. Civic life was never, and will never be, without rhetoric because the language of politics is essentially rhetorical (Rubinelli, 2018, p. 28). Politicians use political rhetoric as art to manipulate language, propagandize their message to the target audience, and achieve persuasive ends.

The central place occupied by translation in human culture has long been recognized. In today's globalized world, it is all too easy to forget that, without this activity, cultural communities would face cultural isolation. Translators now heavily mediate every aspect of our social and political life, contributing to disseminating information all over the world. Furthermore, the primary task of the translator is to translate not what is there but what is not there, to translate the implicit and the assumed, the blank 
spaces between words (Bielsa, Bassnett, 2009, p. 18). As a result, political discourse translation has been the subject of increasing interest in recent years. In brief, language is essential in conducting politics, and political translation plays a vital role in developing political discourse.

The proposed paper aims to analyze the translation strategies used to translate Joseph R. Biden's inaugural address into Ukrainian. The comparative method, discourse analysis, and generalization have been used to conduct the research. There are several important areas where this study contributes. First, examining the research works emphasizing such relevant issues in translation provides perspectives that can complement and refocus some current views on the translation process. Second, for translators, it suggests significant new directions for research focusing on the nature of political language transfer and communication characteristics between speakers of English and Ukrainian.

\section{TRANSLATING POLITICAL DISCOURSE}

Over the past decade, most research in political discourse analysis has focused on the relationship between language and politics. For example, a longitudinal study of political discourse by Chilton (2004) reports that language and politics are intimately linked at a fundamental level. Similarly, Rubinelli $(2018$, p. 17) found that language is essential to politics as politics exercises its power of making decisions and influencing citizens through language. In other words, the relation between language and the political life of the society is quite tight. The former can influence the actual political processes in society.

There are several possible explanations for such insatiable interest in the issues of political communication. First, the proposed type of communication acquires the features of mass manipulation means. Second, the mechanisms of language used to manipulate mass consciousness are regarded as instilling democratic ideas and values. Third, to trace those mechanisms, the scholars need to address political discourse and find suitable methods for its analysis. Indeed, understanding the argumentative nature of political texts is, therefore, key to being able to evaluate 
the political strategies they are a part of (Fairclough, Fairclough, 2012, p. 18).

The term "discourse" embodies a multitude of concepts, yet it is difficult to define precisely. In the mid XXth century, the representatives of Oxford and Cambridge linguistic schools determined the theoretical basis for the study of political discourse. The most promising findings in the area and its systematic study was reported by Dijk (2009). By drawing on the concept of political discourse, the scholar has shown that besides differences in the very construction of social situations as contexts, cultures may also be different in the ways context definitions impinge on text and talk (Dijk, 2009, p. 155).

For research, discourse analysis is widely used. Its primary goal is to describe the coding and interpretation conventions of culture in certain discursive domains, as well as the culture's underlying common ground assumptions (Lauerbach, Fetzer, 2007, p. 7). In addition, it can reveal the hidden sense and show the difference between a politician's speech and his/her real intentions. Finally, the results of such analysis make it possible to uncover baseless promises and manipulative strategies verbalized in linguistic means. The significance of this method in political discourse research is undeniable.

Power, relationality and difference are believed to be key features of world politics in translation (Berger, Esguerra, 2018, p. 2). The central objective of translation studies is thus to explore the specific situation in which power has had an impact on translation activity and cultural development. Translation, understood as a mechanism of other culture's representation, plays an essential role in the contemporary world. It is not merely a linguistic transfer but also a cross-cultural activity (Bánhegyi, 2014, p. 133). The accuracy of translation is achieved not only due to the knowledge of another language's algorithms but also the intersection of the source message and the translator's cultural spaces. In this respect, translations and translators are thus located in very specific social and political contexts and unavoidably exposed to the changes, ruptures, and upheavals that these contexts undergo (Berger, Esguerra, 2018, p. 4).

The fundamental goal of political discourse translation is to trigger the target recipient's reaction somewhat similar to the original speak- 
er's. Regarding this, the translator's role increases in importance. Since political discourse appeals to the hierarchy of values prevalent at a particular stage of society's development, the translator must stop the fertile and enjoyable play of the signifier between literary systems and take a stand (Gentzler, 2002, p. 200). Therefore, the latter has to interpret the source text and find the appropriate linguistic means to preserve its pragmatics and emotionality in the target text fully. Furthermore, political texts are devoid of logical refinement. As a result, certain linguistic stereotypes are involved in translation with "awkward" phrases and often conventional or meaningful word combinations. One must bear in mind that translation process is entangled with certain mental efforts on the part of the translator.

The issues of translation strategies have received considerable attention in translation studies. Some linguists have suggested various strategies for resolving the tension between syntactic and communicative functions in translation. For instance, Mona Baker (2018) lists eight translation strategies employed by professional translators to transfer linguistic and pragmatic meanings from the source language to the target language. They include translation by a more general word, translation by a more neutral/ less expressive word, translation by cultural substitution, translation using a loan word or loan word plus explanation, translation by paraphrase using a related word, translation by paraphrase using unrelated words, translation by omission and translation by illustration. However, the environment where translation takes place inevitably affects the strategies employed by the translator.

\section{TRANSLATION TRANSFORMATIONS IN UKRAINIAN TRANSLATION OF PRESIDENT JOSEPH R. BIDEN'S INAUGURAL ADDRESS}

Political discourse is created to gain, retain and exercise political power. It aims to express views on the world and convince the addressed audience to believe that such a view is undoubtedly correct. While delivering a speech, a speaker depicts future events that may pose a severe challenge 
for a translator, choosing appropriate translation strategies to adequately and accurately render the utterance's meaning.

Baker (2018, p. 94) assumes that the lexical structure of a language, its stock of words and expressions, and its established collocation patterns provide its speakers with ready-made ways of analyzing and reporting experience. In Biden's inaugural speech, lexical strategies or transformations presuppose some semantic changes when semantic equivalents are missing in the target text or are devoid of specific semantic, stylistic, or pragmatic characteristics of the source language unit. They are mainly used to ensure the adequacy of translation.

One of the most widespread lexical transformations in the body of Biden's speech is concretization (or differentiation). It is defined as the replacement of a lexical unit with broader semantics by the word with a narrower meaning. The example proving that the strategy is used in this way is the following sentence found in the body of the speech: With unity we can do great things. Important things. Разом ми здатні на великі справи, важливі справи. In the example above, the translator maintains the structure of the source text in Ukrainian translation while still ensuring the accuracy of the translation. As it can be seen, the translation still conveys the message encoded in the source text. However, the translator makes some modifications by changing the sentence structure in the target text.

The words that fall under concretization are mainly nouns: Millions of jobs have been lost. Hundreds of thousands of businesses closed. Втрачено мільйони робочих місиь, закриті сотні тисяч підприемств. Тоdау, we celebrate the triumph not of a candidate, but of a cause, the cause of deтостасу. Сьогодні ми святкуємо перемогу не кандидата, а справи, справи демократії. A cry for survival comes from the planet itself. Благання про виживання виходить від самої планети. However, in order not to translate the sentences 'freely' the translator tends to make the verbs more concrete in translation: So now, on this hallowed ground where just days ago violence sought to shake this Capitol's very foundation, we come together as one nation, under God, indivisible, to carry out the peaceful transfer of power as we have for more than two centuries. Toмy зараз, на иьому священному місиі, де всього кілька днів тому 
насильство намагалося розхитати саму основу Капітолію, ми зібралися разом, як одна нероздільна зберенена Богом нація, щзоб здійснити мирний перехід влади, так, як ми робили ие понад два століття. A cry for survival comes from the planet itself. Благання про виживання виходить від самої планети. I get it. ... я розумію. nd, if we are this way, our country will be stronger, more prosperous, more ready for the future. Якщо ми це зробимо, наша країна стане сильнішою, успішнішою, краще підготовленою до майбутнього. Obviously, the need for concretization of these lexical units was caused by the discrepancies in the source and target language structures, namely the absence of the corresponding words with broad semantics.

Generalization is a translation strategy that is opposite to concretization. The words in the source and target languages may mismatch. Therefore, the source language unit with narrower semantics is substituted by a lexeme with a broader meaning. For instance, The will of the people has been heard and the will of the pеорle has been heeded. Волевиявлення народу було почуто, і воля народу була почута. We will press forward with speed and urgency, for we have much to do in this winter of peril and possibility. Ми підемо вперед швидко і наполегливо, тому щзо нам багато чого треба зробити иієї зими, сповненої небезпек і значних можливостей.

Retaining the sentence structure of the source text in the target text is essential in translating political speeches because both the content and the form are of equal importance for delivering the communicative intent. Consistent with Baker's viewpoint (2018), a language can, of course, express any information its speakers need to express. However, the grammatical system of a given language will determine the ease with which certain notions can be made explicit. Therefore, to maintain the translation grammatically correct in the target language, the translators introduce morphological or syntactic changes. In the body of Biden's inaugural speech, grammatical transformations are numerous.

In the following example, the part of speech replacement is a strategy rationally applied by the translator: To overcome these challenges - to restore the soul and to secure the future of America - requires more than words. Подолання цих викликів, відродження нашої душі та 
забезпечення безпечного майбутнього Америки вимагає більще, ніж слів. In translation, infinitives are replaced by nouns, yet the translation is still grammatically acceptable in Ukrainian.

To convey the message accurately, the translator needs to change the noun number category. A singular noun in the source text is substituted by the plural one in the target text: This is our historic moment of crisis and challenge, and unity is the path forward. Це наш історичний момент кризи й викликів, і илях вперед передбачає єдність. In our view, this strategy is used not to contradict the grammatical regulations of the target language.

When translating the speech in question from English to Ukrainian, the translator's choice is based on outer partitioning, preserving the communicative intent of both the source and target texts. The examples are as follows: This is a great nation and we are a good people. Це велика нація. Ми хороші люди. Through a crucible for the ages America has been tested anew and America has risen to the challenge. Крізь горнило століть Америка знову пройшла випробування. I Америка відповіла на виклик. Yet we endured and we prevailed. Проте, ми вистояли. Ми перемогли. The right to dissent peaceably, within the guardrails of our Republic, is perhaps our nation's greatest strength. Право на мирну незгоду. В межах кордонів нашої країни, можливо, це найбільша сила нації. Looking more closely, there is no doubt that outer partitioning becomes a justified option in translating compound and complex sentences into Ukrainian.

Sentence integration is the translation transformation that implies the integration of two source language sentences into one target sentence. It is applied in the following examples: With unity we can do great things. Important things. Разом ми здатні на великі справи, важливі справи. Millions of jobs have been lost. Hundreds of thousands of businesses closed. Втрачено мільйони робочих місиь, закриті сотні тисяч підприємств, поклик до расової справедливості, якому щонайменше 400 років, рухає нами. You know the resilience of our Constitution and the strength of our nation. As does President Carter, who I spoke to last night but who cannot be with us today, but whom we salute for his lifetime of service. I я знало стійкість нашої Конституції та силу нашої нації, так само як ие знає президент Картер, з яким я говорив вчора ввечері і який не може 
бути з нами тут сьогодні, але якому ми віддаємо данину поваги за його службу довжиною в життя. Much to repair. Much to restore. Much to heal. Much to build. And much to gain. Багато потрібно виправити, багато відновити, багато загоїти, багато побудувати та багато здобути.

Before applying translation strategies, the translator conducts a pragmatic analysis that enables him/her to decide on the information to be overlooked. For example, let us consider a segment of Joseph R. Biden's speech and its translation: And, in my first act as President, I would like to ask you to join me in a moment of silent prayer to remember all those we lost this past year to the pandemic. Перше, щзо я хотів би зробити, ставии президентом, - це запросити вас приєднатися до мене під час изієі хвилини мовчання і молитви ... The translator managed to preserve the source message content by replacing the parts of the sentence.

Comparing Biden's inaugural address in English and Ukrainian, we can conclude that the source and target language sentences manifest syntactic transformations. The instances of replacement of syndetic coordination by asyndetic are numerous. The following pairs of sentences may serve as a vivid example of employing this translation strategy: Chief Justice Roberts, Vice President Harris, Speaker Pelosi, Leader Schumer, Leader McConnell, Vice President Pence, distinguished guests, and my fellow Americans. Голова Верховного суду США Робертс, віцепрезидент Гарріс, спікер Пелосі, лідер Шумер, лідер Макконелл, віцепрезидент Пенс, шановні гості, мої співгромадяни-американці. And so today, at this time and in this place, let us start afresh. Отже, сьогодні, в ией иас, в иьому місиі, почнім все з чистого аркуша. And here we stand, just days after a riotous mob thought they could use violence to silence the will of the people, to stop the work of our democracy, and to drive us from this sacred ground. I ocb ми стоїмо, всього через кілька днів після того, як бунтівна юрба вирішила, що вона може використовувати насильство, щьоб змусити замовкнути волю людей, зупинити роботу нашої демократіі, вигнати нас з иієї священної землі.

Dealing with the transformations on the syntactic level, we have found that the translator employs the replacement of subordination by coordination (Here we stand looking out to the great Mall where Dr. King spoke of 
his dreaт. Ми стоїмо і дивимося на величну [Національну] алею, де доктор Кінг говорив про свою мрію) and transposition (Over the centuries through storm and strife, in peace and in war, we have come so far. Mu пройшли через століття, крізь шторми і розбрати, мирний $i$ воєнний час, але у нас попереду ще далекий шлях. We face an attack on democracy and on truth. Наша демократія, наша правда піддаються нападам) for the situations designated by both sentences to be identical. The translator's primary goal is to ensure that the communicative function of both utterances is the same.

Sometimes the structure of the sentence can be modified. Any change of the grammatical meaning within the sentence or grammar compensation will avoid discrepancies in the surface structure and the meaning of the sentences: Few periods in our nation's history have been more challenging or difficult than the one we're in nоw. Небагато людей в історії нашої країни стикалися з такими труднощами та викликами, які поставив перед нами час. The battle is perennial. Битва триває роки ...

Trying to maintain the structure and meaning of Biden's speech, the translator also applies complex transformations. The latter concern both the lexical and grammatical levels. While rendering the sentence $A$ oncein-a-century virus silently stalks the country, the translator employed descriptive translation (Вірус, який буває раз на століття, безмовно вражає країну.), which is entirely appropriate in this case and aids to understand the word combination in the right way. The following segments of the source and target language texts demonstrate the same translation transformation in the target language: In another January in Washington, on New Year's Day 1863, Abraham Lincoln signed the Emancipation Proclamation. В іншому січні, у 1863 рочі, в день нового року, Авраам Лінкольн підписав Прокламацію про звільнення рабів. Among the reasons for using hierarchically different target language units to render the elements of the source language, the compressed grammatical structures of the English language can be mentioned.

While rendering the sentence Don't tell me things can't change, the translator's choice falls on antonymic translation (Не кажіть мені, що нічого не можна змінити!). In the above-presented example, it is clearly seen that the affirmative in sense source language unit is substituted for 
a semantically corresponding negative in sense unit of the target language. Thus, by verbalizing an idea with negation, a Ukrainian speaker sounds somewhat more categorical than an English one.

Considering these multiple translation strategies employed while translating Joseph R. Biden's speech into Ukrainian, we can assume that the correct choice of translation means helped to preserve some pathos of the source text and the speaker's communicative intent. The ability to find and use exactly those words retaining a bright image created by a politician and evoking positive emotions in the recipient audience is a highly-demanding translation task. Consequently, it is highly valued in general communication and political discourse in particular.

\section{CONCLUSION}

Reembedding translation strategies in terms of political discourse analysis open up new perspectives to research and highlight the need for studies that focus on linguistic and pragmatic aspects of translation. The proposed paper may also contribute to establishing causal links between political contexts verbalized in English and Ukrainian. Finally, it would be useful to determine empirically translation tendencies universal for political discourse rendered into any language for translation studies at large.

Research evidence shows that the relationship between language and politics appears to be complex. Translating political discourse aims to provoke in a foreign addressee a reaction similar to that of the addressees of the source text. The translator's task is further complicated because political discourse appeals to a hierarchy of values relevant only to the particular culture for which political discourse is created. To faithfully reproduce the text of Biden's inaugural speech in Ukrainian, the translator has applied lexical, grammatical, and complex transformations. They are used in the introductory part, the main body, and the concluding part of the analyzed speech. In short, nationally-specific realities and Biden's peculiarities of speech have been fully reproduced in Ukrainian translation. Linguistic influence in political discourse is complex because the goal 
of any political speech is the speaker's desire to affect the mental, rational, and emotional spheres of the listeners.

This research has thrown up many questions and proved that translating political discourse is an intriguing one that could be usefully explored in further research.

\section{BIBLIOGRAPHY:}

Asoulin, E. (2016). Language as an instrument of thought. Glossa: A Journal of General Linguistics, 1(1): 46, pp. 1-23. Downloaded from https://www.glossa-journal.org/ articles/10.5334/gjgl.34/.

Baker, M. (2018). In Other Words: A Coursebook on Translation. 3rd ed. London and New York: Routledge Taylor and Francis Group. doi: 10.4324/9781315619187.

Bánhegyi, M. (2014). Translation and Political Discourse. Acta Universitatis Sapientiae, Philologica, 6 (2), pp. 139-158.

Berger, T., Esguerra, A. (2018). The Objects of Translation. In: T. Berger \& A. Esguerra (eds.), World Politics in Translation: Power, Relationality and Difference in Global Cooperation (pp. 1-21). London / New York: Routledge Taylor and Francis Group.

Bielsa, E. \& Bassnett, S. (2009). Translation in Global News. London, New York: Routledge Taylor and Francis Group.

Chilton, P. (2004). Analysing Political Discourse: Theory and Practice. London, New York: Routledge Taylor and Francis Group.

Dijk, van T.A. (2009). Society and Discourse: How Social Contexts Influence Text and Talk. Cambridge: Cambridge University Press.

Fairclough, I., Fairclough, N. (2012). Political Discourse Analysis. London, New York: Routledge Taylor and Francis Group.

Gentzler, E. (2002). Translation, Poststructuralism, and Power. In: M. Tymoczko, E. Gentzler (eds.), Translation and Power (pp. 195-218). Amberst / Boston: University of Massachusetts Press.

Biden, J.R. (2021). Inaugural Address by President Joseph R. Biden, Jr. Downloaded from https://www.whitehouse.gov/briefing-room/speeches-remarks/2021/01/20/ inaugural-address-by-president-joseph-r-biden-jr/

https://ua.usembassy.gov/uk/inaugural-address-by-president-joseph-r-biden-jr/.

Lauerbach, G.V., Fetzer, A. (2007). Political Discourse in the Media: Cross-cultural Perspectives. In: G.V. Lauerbach, A. Fetzer (eds.), Political Discourse in the Media: Crosscultural Perspectives (pp. 3-30). Amsterdam / Philadelphia: John Benjamins Publishing Company. 
Marszałek-Kawa, J., Plecka, D. (ed.). (2019). J. Marszałek-Kawa, D. Plecka (eds.). Dictionary of Political Knowledge. Toruń: Wydawnictwo Adam Marszałek.

Rubinelli, S. (2018). Rhetoric as a Civic Art from Antiquity to the Beginning of Modernity. In: R. Wodak \& B. Forchtner, The Routledge Handbook of Language and Politics (pp. 17-29). London, New York: Routledge Taylor and Francis Group.

Sharifian, F. (2017). Cultural Linguistics: Cultural Conceptualizations and Language. Amsterdam/Philadelphia: John Benjamins Publishing Company. 